\title{
Pengaruh Ukuran Perusahaan, dan Leverange Terhadap Praktik Income Smoothing pada Bank Syariah
}

\author{
Syawal Harianto ${ }^{1}$, Haris Al Amin ${ }^{2}$, Yusmika Indah ${ }^{3}$ \\ 1,2,3 Program studi Akuntansi lembaga keuangan syariah \\ Jurusan Tata Niaga Politeknik Negeri Lhokseumawe, \\ Indonesia
}

\begin{abstract}
Abstrak. Penelitian ini bertujuan untuk. mengetahui pengaruh ukuran perusahaan dan financial leverage terbadap praktik Income Smoothing pada bank syariah. Data yang digunakan adalah data sekunder yang bersumber dari data tabunan yang dipublikasikan oleb bank. umum syariah dan unit usaba syariah Periode tabun 2016-2018, sampel penelitian berjumlah 54 (lima puluh empat) bank. Teknik analisis data menggunakan Eviews dengan model Fixed Effect. Hasil penelitian menunjukkean bahwa secara simultan ukuran perusabaan dan financial leverage berpengaruh signifikan terbadap praktik. Income Smoothing pada bank syariah. Secara parsial Ukuran Perusahaan dan Financial Leverage masing-masing memiliki pengaruh positif dan signifikan terhadap praktik. Income Smoothing. Hasil uji determinasi yang digunakan adalab 55\%.
\end{abstract}

Kata kunci: Ukuran Perusahaan, Financial Leverage, Income Smoothing.

Abstract. This research is to know the effect of firm size, and financial leverage to Income Smoothing practices is Islamic Banks. The data used is the secondary data with sourced from annual report data published by Islamic commercial banks and syariah business unit during 2016-2018 periods, samples research are 54 (fifty four) bank. Data analysis method using eviews with the fixed effect model. The result of the research shows that the simultan firm size and financial leverage have significant effect on Income Smoothing in Islamic banks.the partially, firm size an financial leverage has a positive and significant effect on income smoothin practices in Islamic banks City. The determination test result is $55 \%$.

Keywords: Firm Size, Financial leverage, Income Smoothing. 


\section{Pendahuluan}

Laporan keuangan merupakan sumber informasi yang digunakan sebagai salah satu instrumen dalam menilai kinerja perusahaan. Tujuan utama laporan keuangan adalah untuk menyedian informasi, menyangkut posisi keuangan, kinerja serta perubahan posisi keuangan suatu entitas syariah yang bermanfaat bagi sejumlah besar pemakai dalam pengambilan keputusan ekonomik. Laporan keuangan diharapkan dapat memenuhi kebutuhan bersama sebagai bentuk laporan dan pertanggungjawaban manajemen atas sumber daya yang dipercayakan kepadanya (Sry Nurhayati dan Wasilah, 2015).

Praktik Income Smoothing dilakukan manajemen menjadi salah satu cara dengan tujuan menaikkan atau menurunkan laba guna mengurangi fluktuasi laba sehingga pada laporan keuangan yang di susun bank akan terlihat stabil dengan mempertimbangkan tingkat pertumbuhan normal. Praktik Income Smootbing dipengaruhi oleh berbagai faktor pendorongnya. Hasil penilitain membuktikan bahwa ukuran perusahaan berpengaruh posiitif terhadap praktik perataan laba Rahmawati dan Muid (2012). Sedangkan penelitian Kusnadi (2015) menunjukan hasil bahwa ukuran perusahaan tidak berpengaruh signifikan terhadap praktik perataan laba.

Berdasarkan statistik perbankan syariah (SPS) Otoritas Jasa Keuangan (OJK), Laba gabungan bank umum syariah dan unit usaha syariah tercatat tumbuh lebih tinggi dibandingkan dengan bank umum konvensional pada kuartal I/2020. Laba bersih perbankan syariah pada kuartal I/2020 tercatat senilai Rp2,18 triliun atau tumbuh 39,48 persen dibandingkan dengan periode sama tahun lalu (year on year/YoY). Sementara itu, laba bank umum konvensional pada kuartal I/2020 adalah senilai Rp42,83 triliun atau tumbuh 6,43 persen YoY. Kemudian dari catatan Otoritas Jasa Keuangan (OJK) per Oktober 2019 kinerja bank syariah memang masih mumpuni. Hal ini dikarenakan bank syariah berhasil mencatat pertumbuhan pembiayaan 11,03\% (yoy), pertumbuhan dana pihak ketiga $10,16 \%$ (yoy), dan pertumbuhan laba berjalan mencapai 46,60\% (yoy).
Berdasarkan dari pencapaian yang telah diraih bank syariah pada dua tahun terakhir menunjukkan bahwa terdapaya upaya besar yang dilakukan bank syariah dalam mencapai tingkat laba yang tinggi. Salah satu upaya yang mungkin dilakukan oleh Bank Syariah yaitu dengan melakukan Praktik Perataan Laba (Income Smoothing) sehingga laba yang dihasilkan akan lebih stabil dari tahun ke tahun. Penerapan Income Smoothing di Indonesia terutama pada Bank Syariah masih menjadi hal yang baru, artinya belum semua bank melakukan praktik Income Smoothing tersebut sehingga akan sangat menarik untuk di teliti. Terdapat dua faktor yang dapat mempengaruhi perbankan syariah dalam melakukan Praktik Income Smoothing yaitu Ukuran Perusahan (Firm Size) dan Financial Leverage.

\section{Literature Review}

\section{Income Smoothing}

Perataan laba atau Income Smoothing adalah meratakan earnings yang dilaporkan atas pengurangan secara sengaja fluktuasi di sekitar tingkat earnings tertentu yang dianggap normal bagi suatu perusahaan (Masodah, 2017). Kemudian Income Smoothing adalah suatu tindakan yang sengaja dilakukan oleh manajer dengan menggunakan kebijakan akuntansi untuk mengurangi fluktuasi laba (Muklas, 2012).

Tujuan dari Income Smoothing adalah salah satu bentuk kegiatan yang dilaksanakan manajemen agar bisa menaikkan market returns (Dewi, Kartika dan Zulaikha, 2011). Ada beberapa motivasi yang dapat mendorong praktik Income Smoothing menurut Sulistyanto (2014) yaitu: motivasi utang, motivasi bonus, motivasi penjualan saham, motivasi pajak dan pergantian direksi. Rumus pengukuran Income Smoothing menurut (Eckel, 1981), berdasarkan Indeks Eckel:

Keterangan:

$$
\text { Indeks Eckel }=\frac{\mathrm{CV} \Delta \mathrm{I}}{\mathrm{CV} \Delta \mathrm{S}}
$$

$\Delta \mathrm{I}$ : Perubahan laba bersih dalam satu periode $\Delta S$ : Perubahan pendapatan dalam satu periode $\mathrm{CV}$ : Koefisien variasi

\section{Ukuran Perusahaan}

Ukuran perusahaan menggambarkan besar kecilnya suatu perusahaan yang dapat ditunjukkan oleh total aktiva, jumlah penjualan, rata-rata total penjualan dan rata-rata total aktiva 
(Tiara, 2012). Pengaruh positif ukuran perusahaan terhadap perataan laba berdasarkan Utomo dan Siregar (2008) adalah bahwa perusahaan yang mempunyai size besar cenderung akan melakukan perataan laba jika dibandingkan dengan perusahaan kecil karena perusahaan besar memiliki perhatian yang lebih dari publik serta pemerintah, sehingga perusahaan tersebut akan dipandang bagus oleh publik karena laba yang dihasilkan cenderung stabil.

Semakin baik kualitas laporan keuangan yang disajikan maka akan semakin meyakinkan pihak eksternal dalam melihat kinerja keuangan perusahaan tersebut, yang otomatis tentunya pihak-pihak yang berhubungan dengan perusahaan akan merasa puas dalam berbagai urusan dengan perusahaan (Fahmi, 2013). Ukuran perusahaan dengan mengunakan pendekatan total asset berdasarkan pertimbangan bahwa total asset dapat mencerminkan ukuran perusahaan, sehingga dapat dirumuskan sebagai berikut:

\section{Ukuran Perusahaan $=$ Ln Total Asset}

\section{Financial Leverage}

Financial leverage merupakan hal penting dalam penentuan struktur modal perusahaan dan merupakan salah satu rasio utang. Hutang (leverage) adalah semua kewajiban keuangan perusahaan pada pihak lain yang belum terpenuhi, dimana hutang ini merupakan sumber dana atau modal yang berasal dari kreditor (Fatmawati, 2015).

Financial leverage diukur dengan membandingkan antara total hutang dan total aktiva. Financial leverage menunjukkan proporsi penggunaan utang untuk membiayai investasinya. Financial leverage atau disebut juga leverage factor adalah rasio nilai buku seluruh hutang terhadap total aktiva (Bestivano, 2013). Financial leverage dapat diproksikan dengan Debt to total Aset (DTA) (Fatmawati, 2015). Kemampuan perusahaan untuk melunasi hutang dengan aktiva yang dimiliki perusahaan. Secara matematis perhitungan Debt to Total Aset yang terdapat dalam Fatmawati (2015) untuk mendapatkan nilai Financial Leverage yaitu:

\section{Debt to Total Asset $=\frac{\text { Total Hutang }}{\text { Total Aktiva }}$}

\section{Bank Syariah}

Undang-Undang Nomor 21 Tahun 2008 tentang perbankan syariah, yang dimaksud dengan bank syariah adalah bank yang kegiatan usahanya didasarkan pada prinsip syariah. Bank Syariah adalah lembaga keuangan negara yang memberikan kredit dan jasa-jasa lainnya di dalam lalu lintas pembayaran dan juga peredaran uang yang beroperasi dengan menggunakan prinsipprinsip syariah atau Islam (Sudarsono, 2012). Unit Usaha Syariah (UUS) UU Nomor 21 tahun 2008 adalah unit kerja dari kantor pusat bank Umum Konvensional yang berfungsi sebagai kantor induk dari kantor atau unit yang melaksanakan kegiatan usaha yang berdasarkan prinsip syariah.

\section{Metodologi Penelitian}

Ruang lingkup dalam penelitian ini merupakan seluruh Bank Umum Syariah dan Unit Usaha Syariah di Indonesia. Tujuan penelitian ini adalah untuk mengetahui hubungan antar variabel independen yaitu Ukuran Perusahaan dan Financial Leverage terhadap variabel dependen yaitu Income Smoothing. Metode penentuan sampel yang digunakan dalam penelitian ini adalah Metode Purposive Sampling. Sampel dalam penelitian ini didasarkan pada Perhitungan Indeks Eckel. Sampel yang akan digunakan hanya Bank Syariah yang berdasarkan hasil Indeks Eckel melakukan Income Smoothing.

\section{Teknik Analisis Data}

Penelitian ini menggunakan metode Analisis Regresi Linear Berganda dengan menggunakan Eview. Adapun persamaan yang digunakan dalam penelitian ini yaitu:

Dimana:

$$
\mathrm{Y}=\alpha_{0}+\alpha_{1} \operatorname{LnX}_{1}+\alpha_{2} \mathrm{X}_{2}+\mathrm{e}
$$

$$
\begin{array}{ll}
\mathrm{Y} & =\text { Income Smoothing } \\
\mathrm{a} \alpha_{0} & =\text { Konstanta } \\
\mathrm{a} \alpha_{1}-\alpha_{2} & =\text { Koefisien Regresi } \\
\mathrm{aX} & =\text { Ukuran Perusahaan } \\
\mathrm{X}_{2} & =\text { Financial Leverage } \\
\mathrm{Ln} & =\text { Logaritma Natural } \\
\mathrm{e} & =\text { Errorterm }
\end{array}
$$




\section{Perhitungan Indeks Eckel}

Model yang biasa digunakan untuk mendeteksi Income Smoothing adalab Indeks Eckel. Index Eckel akan membandingkan kovarian laba dengan kovarian pendapatan yang diperoleh bank tersebut dalam suatu periode. Sehingga rumus Indeks Eckel yaitu: $\mathrm{CV} \Delta \mathrm{I} / \mathrm{CV} \Delta \mathrm{S}$.

Bank Syariah dapat dikategorikan melakukan praktik Income Smoothing apabila memperoleh nilai Indeks Eckel lebih kecil dari satu (Indeks Eckel < 1), sedangkan perusahaan yang memperoleh Indeks Eckel lebih dari satu atau sama dengan satu (Indeks Eckel $\geq 1$ ) dikategorikan sebagai perusahaan yang tidak melakukan praktik Income Smoothing (Dewantiana, 2009).
(Perataan Laba) pada Bank Syariah di Indonesia.

\section{Hasil dan Pembahasan Uji Asumsi Klasik}

Analisis data dilakukan dengan menggunakan model regresi linier berganda untuk mengetahui ada atau tidaknya pengaruh variabel independen terhadap variabel dependen. Dalam analisis regresi linier berganda diharuskan adanya beberapa asumsi yang harus dipenuhi agar penaksiran atau koefisien regresi tidak bias dan dapat mendeteksi keadaan yang sesungguhnya (Best Linear Unbiased Estimator atau BLUE) (Andriyan, 2010).

Uji Multikolinearitas

Tabel 1. Perhitungan Indeks Eckel untuk Bank Umum Syariah dan Unit Usaha Syariah

\begin{tabular}{|c|c|c|c|c|c|c|}
\hline No & NAMA BANK & CV $\Delta \mathrm{I}$ & $\mathrm{CV} \Delta \mathrm{S}$ & $\begin{array}{l}\text { Nilai Indeks Eckel } \\
\text { (CV } \Delta \mathrm{I} / \mathrm{CV} \Delta \mathrm{S})\end{array}$ & $\begin{array}{l}\text { Income } \\
\text { Smoothing }\end{array}$ & Keterangan \\
\hline 1 & PT Bank BNI Syariah & $2.652 .148,68$ & $38.447,78$ & 68,98 & 0 & 'Tidak Melakukan Income Smoothing \\
\hline 2 & PT Bank Mega Syariah & $167.384,77$ & $219.225,63$ & 0,76 & 1 & Melakukan Income Smootbing \\
\hline 3 & $\begin{array}{l}\text { PT Bank Muamalat } \\
\text { Indonesia }\end{array}$ & $435.613,02$ & $968.135,53$ & 0,45 & 1 & Melakukan Income Smootbing \\
\hline 4 & PT Bank Syariah Mandiri & $558.049,22$ & $248.342,12$ & 2,25 & 0 & Tidak Melakukan Income Smoothing \\
\hline 5 & PT Bank BCA Syariah & $59.507,23$ & $3.906,38$ & 15,23 & 0 & 'Tidak Melakukan Income Smootbing \\
\hline 6 & PT Bank Bri Syariah & $439.050,01$ & $684.868,25$ & 0,64 & 1 & Melakukan Income Smootbing \\
\hline 7 & $\begin{array}{l}\text { PT Bank Jabar Banten } \\
\text { Syariah }\end{array}$ & $218.878,19$ & $1.112,65$ & 196,72 & 0 & 'Tidak Melakukan Income Smootbing \\
\hline 8 & PT Bank Panin Syariah & $2.987 .044,67$ & $4.413 .417,59$ & 0,68 & 1 & Melakukan Income Smootbing \\
\hline 9 & PT Bank Syariah Bukopin & $359.092,47$ & $598.375,38$ & 0,6 & 1 & Melakukan Income Smootbring \\
\hline 10 & PT Bank Victoria Syariah & $104.401,01$ & $30.036,86$ & 3,48 & 0 & 'Tidak Melakukan Income Smoothing \\
\hline 11 & $\begin{array}{l}\text { PT Bank Maybank Syariah } \\
\text { Indonesia }\end{array}$ & $369.617,73$ & $377.455,67$ & 0,98 & 1 & Melakukan Income Smootbring \\
\hline 12 & PT Bank Aceh Syariah & $342.294,26$ & $390.742,12$ & 0,88 & 1 & Melakukan Income Smootbring \\
\hline 13 & PT Bank NTB Syariah & $426.530,83$ & $729.670,87$ & 0,58 & 1 & Melakukan Income Smootbring \\
\hline 14 & $\begin{array}{l}\text { PT Bank Tabungan } \\
\text { Pensiunan Nasional Syariah } \\
\text { PT Bank Danamon }\end{array}$ & $464.648,71$ & $2.752 .221,71$ & 0,17 & 1 & Melakukan Income Smootbing \\
\hline 15 & Indonesia, Tbk & 1022,71 & 30,41 & 33,63 & 0 & 'Tidak Melakukan Income Smootbing \\
\hline 16 & PT Bank Permata, Tbk & 933,77 & 186,74 & 5,00 & 0 & 'Tidak Melakukan Income Smoothing \\
\hline 17 & $\begin{array}{l}\text { PT Bank CIMB Niaga, Tbk } \\
\text { PT Bank OCBC NISP, }\end{array}$ & 2718,02 & 52,95 & 51,33 & 0 & 'Tidak Melakukan Income Smoothing \\
\hline 18 & Tbk & 309,98 & 88,19 & 3,51 & 0 & Tidak Melakukan Income Smoothing \\
\hline 19 & PT Bank Sinarmas & 1765,30 & 23,82 & 74,10 & 0 & 'Tidak Melakukan Income Smoothing \\
\hline 20 & $\begin{array}{l}\text { PT Bank Tabungan Negara } \\
\text { (Persero), Tbk. }\end{array}$ & 1046,29 & 66,79 & 15,66 & 0 & Tidak Melakukan Income Smoothing \\
\hline 21 & PT BPD DKI & 222,77 & 62387,12 & 0,00 & 1 & Melakukan Income Smootbing \\
\hline
\end{tabular}

Sumber : Hasil Penelitian (Diolah), 2020

Dari tabel 1. 33 Bank Syariah di Indonesia yang terdiri dari Bank Syariah dan Unit Usaha Syariah terdapat 18 (delapan belas) bank syariah yang terdiri dari Bank Umum Syariah dan Unit Usaha Syariah atau sebesar 55\% yang melakukan praktik Income Smoothing. Kemudian 5 (Lima) Bank Syariah di Indonesia atau sebesar 40\% yang tidak melakukan Praktik Income Smoothing
Uji multikolinearitas bertujuan untuk menguji apakah suatu model regresi terdapat korelasi antar variabel bebas (independen) yang terdapat dalam suatu penelitian. Model regresi yang baik seharusnya tidak terjadi korelasi antar variabel independen dikarenakan dapat menghasilkan kesimpulan yang tidak baik (Ghozali, 2012). Berikut hasil Uji Multikolinearitas yang dilakukan dengan SPSS yaitu. 
Tabel 2. Hasil Uji Multikolinearitas

Coefficients $^{2}$

\begin{tabular}{|c|c|c|c|c|c|c|c|c|}
\hline \multirow{2}{*}{\multicolumn{2}{|c|}{ Model }} & \multicolumn{2}{|c|}{$\begin{array}{c}\text { Unstandardized } \\
\text { Coefficients }\end{array}$} & \multirow{2}{*}{$\begin{array}{c}\begin{array}{c}\text { Standardized } \\
\text { Coefficients }\end{array} \\
\text { Beta }\end{array}$} & \multirow[b]{2}{*}{ t } & \multirow[b]{2}{*}{ Sig. } & \multicolumn{2}{|c|}{$\begin{array}{l}\text { Collinearity } \\
\text { Statistics }\end{array}$} \\
\hline & & B & Std. Error & & & & Tolerance & VIF \\
\hline \multirow[t]{3}{*}{1} & (Constant) & .312 & .264 & & 1.181 & .243 & & \\
\hline & $\begin{array}{l}\text { Ukuran_Perusahaa } \\
\text { n }\end{array}$ & .010 & .008 & .286 & 1.318 & .193 & .381 & 2.624 \\
\hline & Financial_Leverage & .000 & .102 & -.001 & -.002 & .998 & .381 & 2.624 \\
\hline
\end{tabular}

a. Dependent Variable: Income_Smoothing

Sumber: Hasil Penelitian (Diolah), 2020

Dari hasil uji yang terdapat pada tabel di atas untuk melihat terjadi gejala Multikolinearitas dapat dilihat dengan nilai tolerance dan nilai VIF (Variance Inflation Factor). Dari hasil diatas dapat dilihat nilai Tolerance semua variabel independen lebih besar dari 0,1 atau 10\%. Hal ini dapat dibuktikan dengan Nilai Tolerance dari variabel Ukuran Perusahaan dan Financial Leverage yaitu $0,381>0,1$.

Jika dilihat dari nilai VIF maka nilai VIF dari kedua variabel independen lebih kecil dari 10. Hal ini dibuktikan dengan Nilai VIF variabel Ukuran Perusahaan dan Financial Leverage yaitu $2,624<10$. Jadi berdasarkan hasil uji diatas dapat disimpulkan bahwa nilai tolerance kedua variabel independen $>10 \%$ dan nilai $\mathrm{VIF}<10$ sehingga dapat diartikan bahwa pada penelitian ini tidak terjadi masalah Multikolinearitas.

\section{Uji Heterokedastisitas}

Uji heteroskedastisitas bertujuan untuk menguji apakah dalam model regresi terjadi ketidaksamaan variancedari residual satu pengamat ke pengamat yang lain (Ghozali, 2013). Uji ini dilakukan untuk mengetahui apakah dalam sebuah model regresi terjadi ketidaksamaan varians dari residual suatu pengamatan ke pengamatan lainnya (Umar, 2011).

Mendeteksi ada tidaknya heterokedastisitas dilakukan dengan melihat ada tidaknya pola tertentu pada grafik Scatterplot antara SPRESID dan ZPRED dimana sumbu Y adalah residual. Berikut ini hasil Uji Heterokedastisitas dengan menggunakan SPSS pada Bank Syariah di Indonesia pada rentang tahun 2016-2018.

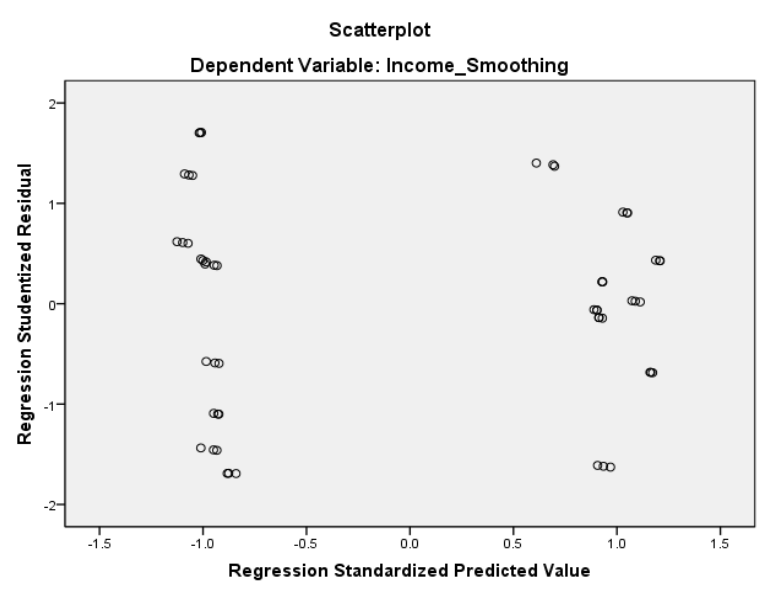

Gambar 1. Hasil Uji Heterokedastisitas Sumber: Hasil Penelitian (Diolah), 2020

Dari gambar 1, dapat dilihat bahwa tidak terdapat pola yang jelas, serta titik-titik menyebar secara merata di atas dan dibawah angka 0 (Nol) pada garis Regression Standardized Residual dan Regression Standardized Predicted V alue. Maka dapat disimpulkan pada data tersebut tidak terjadi masalah Heterokedastisitas.

\section{Hasil Uji Regresi Linear Berganda}

Persamaan regresi linear berganda digunakan untuk menjelaskan hubungan antara variabel independen dengan variabel dependen.

Tabel 3. Analisis Regresi Linear Berganda

\begin{tabular}{|c|c|c|c|}
\hline Variable & Coefficient & Std. Error t-Statistic & Prob. \\
\hline $\mathrm{C}$ & 0.523889 & $3.52 \mathrm{E}-13 \quad 3.493412$ & 0.0000 \\
\hline $\mathrm{X} 1$ & 9.077814 & $1.58 \mathrm{E}-142.744306$ & 0.0003 \\
\hline $\mathrm{X} 2$ & 1.957114 & $1.47 \mathrm{E}-142.324405$ & 0.0142 \\
\hline
\end{tabular}

Sumber: Hasil Penelitian (Diolah), 2020

Berdasarkan hasil pengolahan data diatas apabila diuraikan dalam model penelitia, maka persamaan model regresi linear berganda adalah:

$Y=0,52388+9,07781 X_{1}+1,957114 X_{2}+e$ 
Koefisien-koefisien pada persamaan regresi linear berganda diatas dapat dijelaskan sebagai berikut:

1. Nilai konstanta model persamaan regresi dalam penelitian ini adalah sebesar 0,523889 yang berarti jika kedua variabel independen yaitu Ukuran Perusahaan dan Financial Leverage diasumsikan bernilai 0 (nol), maka besarnya nilai Income Smoothing adalah 0,52388 .

2. Nilai koefisien regresi untuk Ukuran Perusahaan $\left(\mathrm{X}_{1}\right)$ bersifat positif yaitu sebesar 9,07781. Nilai koefisien positif menunjukkan bahwa Ukuran Perusahaan $\left(\mathrm{X}_{1}\right)$ berpengaruh positif terhadap tingkat Perataan Laba (Income Smoothing). Artinya jika variabel lain nilainya tetap dan Ukuran Perusahaan $\left(\mathrm{X}_{1}\right)$ mengalami kenaikan sebesar 1, maka tingkat Income Smoothing (Y) akan mengalami kenaikan sebesar 9,077814 .

3. Nilai koefisien regresi untuk Financial Leverage $\left(\mathrm{X}_{2}\right)$ bersifat positif yaitu sebesar 1,957114. Nilai koefisien positif menunjukkan bahwa Financial Leverage $\left(\mathrm{X}_{2}\right)$ berpengaruh positif terhadap tingkat Perataan Laba (Income Smoothing). Artinya jika variabel lain nilainya tetap dan Financial Leverage $\left(\mathrm{X}_{2}\right)$ mengalami kenaikan sebesar 1 , maka tingkat Income Smoothing (Y) akan mengalami kenaikan sebesar 1,957114.

\section{Uji Chow}

Berdasarkan hasil analisis dengan tiga model data panel yaitu Fixed Effect, Common Effect dan Random Effect yang telah dilakukan dalam penelitian ini, maka akan dilakukan pengujian dengan menggunakan Uji Chow/Likelihood Ratio Test. Uji Chow dilakukan untuk memilih uji yang akan digunakan pada penelitian ini antara Common Effect atau Fixed Effect. Hasil dari Uji Chow dapat dilihat berikut ini:

Tabel 4. Hasil Uji Chow

Redundant Fixed Effects Tests

Equation: Untitled

Test cross-section fixed effects

\begin{tabular}{|c|c|c|}
\hline Effects Test & Statistic & df Prob. \\
\hline Cross-section $\mathrm{F}$ & \multicolumn{2}{|c|}{$0.094722(17,34) 0.0000$} \\
\hline $\begin{array}{l}\text { Cross-section Chi- } \\
\text { square }\end{array}$ & 33.792824 & 170.0000 \\
\hline
\end{tabular}

Sumber: Hasil Penelitian (Diolah), 2020
Berdasarkan hasil Uji Chow pada tabel diatas dapat diketahui nilai probabilitas yaitu 0,000 untuk Cross-section Chi-square, yang berarti lebih kecil dari 0,05 sehingga dengan tingkat keyakinan 95\% model Fixed Effect lebih baik digunakan dalam penelitian ini dibandingkan dengan model Common Effect.

\section{Uji Hausman}

Berdasarkan dari hasil uji Chow diatas maka dilakukan pengujian sekali lagi dengan menggunakan Uji Hausman. Uji Hausman merupakan uji signifikansi untuk memilih uji mana yang lebih baik yang akan digunakan pada penelitian ini antara Fixed Effect atau Random Effect. Hasil dari Uji Hausman dapat dilihat berikut ini:

Tabel 5. Hasil Uji Hausman

Correlated Random Effects - Hausman

Test

Equation: Untitled

Test cross-section random effects

\begin{tabular}{|c|c|c|c|}
\hline Test Summary & $\begin{array}{l}\text { Chi-Sq. } \\
\text { Statistic }\end{array}$ & $\begin{array}{r}\text { Chi-Sq. } \\
\text { df. }\end{array}$ & Prob. \\
\hline $\begin{array}{l}\text { Cross-section } \\
\text { random }\end{array}$ & 0.03621 & 2 & 0.0042 \\
\hline
\end{tabular}

Sumber: Hasil Penelitian (Diolah), 2020

Berdasarkan hasil Uji Hausman diatas dapat dilihat bahwa nilai probabilitas yaitu 0,0042 untuk Cross-Section Random, yang berarti lebih kecil dari 0,05 sehingga dapat diambil keputusan yaitu dengan tingkat keyakinan 95\% model Fixed Effect lebih baik digunakan dalam penelitian ini dibandingkan dengan model Random Effect.

\section{Uji Hipotesis}

Hipotesis adalah jawaban sementara terhadap rumusan masalah penelitian. Kebenaran dari hipotesis itu harus dibuktikan melalui data yang terkumpul. (Sugiyono, 2014).

\section{Uji Signifikansi Parsial (Uji t)}

Uji t digunakan untuk menguji apakah Ukuran Perusahaan dan Financial Leverage berpengaruh secara parsial terhadap Income Smoothing dengan menggunakan alat analisis yaitu Eviews dengan metode pengujian yaitu Fixed Effect. Uji regresi parsial merupakan pengujian yang dilakukan untuk melihat pengaruh dari variabel independen secara individu terhadap variabel dependen atau variabel terikat (Ghozali, 2013:98). Berikut 
merupakan hipotesis yang diajukan pada Uji Signifikansi Parsial yaitu:

$\mathrm{H}_{01}$ : Ukuran Perusahaan dan Financial leverage secara parsial tidak berpengaruh terhadap Income Smoothing pada bank syariah di Indonesia

$\mathrm{H}_{\mathrm{a} 1}$ : Ukuran Perusahaan dan dan Financial leverage secara parsial berpengaruh terhadap Income Smoothing pada bank syariah di Indonesia

Tabel 6. Hasil Uji Signifikansi Parsial (Uji t)

Dependent Variable: Y

Method: Panel Least Squares

Date: 07/24/20 Time: 02:25

Sample: 20162018

Periods included: 3

Cross-sections included: 18

Total panel (balanced) observations: 54

\begin{tabular}{ccccc}
\hline Variable & Coefficient & Std. Error & t-Statistic & Prob. \\
\hline $\mathrm{C}$ & 0.523889 & $3.52 \mathrm{E}-13$ & 3.493412 & 0.0000 \\
$\mathrm{X} 1$ & 9.077814 & $1.58 \mathrm{E}-14$ & 2.744306 & 0.0003 \\
$\mathrm{X} 2$ & 1.957114 & $1.47 \mathrm{E}-14$ & 2.324405 & 0.0142 \\
\hline \multicolumn{5}{c}{ Effects Specification } \\
\hline
\end{tabular}

Sumber: Hasil Penelitian (Diolah), 2020

Hasil uji signifikansi pada tabel diatas untuk Ukuran Perusahaan sebagai variabel independen diperoleh nilai $t$ hitung sebesar $2,744306>\mathrm{t}$ tabel $(2,00758)$ serta nilai prob. yaitu sebesar $0,0003<\alpha(0,05)$ dengan demikian $\mathrm{H}_{\mathrm{a} 1}$ diterima dan $\mathrm{H}_{01}$ ditolak, atau dapat dikatakan bahwa Ukuran Perusahaan mempunyai pengaruh secara signifikan terhadap Income Smoothing pada Bank Syariah di Indonesia tahun 2016-2018.

Financial Leverage hasil uji signifikansi pada tabel diatas yaitu diperoleh nilai t hitung sebesar $2.324405>$ t tabel (2.00758) serta nilai prob. yaitu sebesar $0,00142<\alpha(0,05)$ dengan demikian $\mathrm{H}_{\mathrm{a} 1}$ diterima dan $\mathrm{H}_{01}$ ditolak, atau dapat dikatakan bahwa Financial Leverage mempunyai pengaruh secara signifikan terhadap Income Smoothing pada Bank Syariah tahun 2016-2018.

\section{Uji Signifikansi Simultan (Uji F)}

Uji $\mathrm{F}$ ini merupakan pengujian yang diperlukan dalam menguji hipotesis yang diajukan dalam penelitian ini. Hipotesis biasanya akan diuji dengan menggunakan tingkat signifikansi sebesar 5\% atau 0,05 (Ghozali, 2013: 98).
Hipotesis yang diajukan untuk penelitian ini adalah:

$\begin{aligned} \mathrm{H}_{02} \text { : } & \text { Ukuran Perusahaan dan Financial } \\ & \text { leverage secara simultan tidak } \\ & \text { berpengaruh terhadap Income } \\ & \text { Smoothing pada bank syariah di } \\ & \text { Indonesia } \\ \mathrm{H}_{\mathrm{a} 2} \text { : } & \text { Ukuran Perusahaan dan Financial } \\ & \text { leverage secara simultan berpengaruh } \\ & \text { terhadap Income Smoothing pada bank } \\ & \text { syariah di Indonesia }\end{aligned}$

Tabel 7. Hasil Uji Signifikansi Simultan (Uji F) Cross-section fixed (dummy variables)

\begin{tabular}{lllr}
\hline R-squared & 0.546239 & Mean dependent var & 0.523889 \\
Adjusted R-squared & 0.612758 & S.D. dependent var & 0.305536 \\
S.E. of regression & $1.78 \mathrm{E}-14$ & Akaike info criterion & -60.20645 \\
Sum squared resid & $1.07 \mathrm{E}-26$ & Schwarz criterion & -59.46979 \\
Log likelihood & 1645.574 & Hannan-Quinn criter. & -59.92235 \\
F-statistic & 8.251226 & Durbin-Watson stat & 1.814269 \\
Prob(F-statistic) & 0.000000 & & \\
\hline
\end{tabular}

Sumber: Hasil Penelitian (Diolah), 2020

Hasil pengujian bahwa nilai $\mathrm{F}$ hitung sebesar 8,251226 yang lebih besar dari $F$ tabel yaitu 3,18. Nilai signifikansi $\mathrm{F}$ hitung diperoleh sebesar 0,000000 yang lebih kecil dari tingkat $\alpha$ yang ditetapkan yaitu sebesar 0,05. Dari hasil dapat disimpulkan bahwa $\mathrm{H}_{\mathrm{a} 2}$ diterima dan $\mathrm{H}_{02}$ ditolak. Artinya terdapat pengaruh secara simultan yang signifikan dari Ukuran Perusahaan dan Financial Leverage terhadap praktik Income Smoothing pada Bank Syariah di Indonesia tahun 2016-2018.

\section{Koefisien Determinasi (R-Square)}

Koefisien Determinasi digunakan untuk mengukur seberapa jauh kemampuan model dalam menjelaskan variasi pada variabel dependen (Ghozali, 2012). Nilai Koefisien Determinasi $\left(R^{2}\right)$ berkisar antara nol (0) sampai dengan satu. Apabila nilai $\mathrm{R}$ Square semakin mendekati satu, maka variabel independen memberikan semua informasi yang dibutuhkan untuk memprediksi variabel dan sebaliknya. Berikut merupakan hasil dari Koefisien Determinasi $\left(R^{2}\right)$.

Tabel 8. Hasil Koefisien Determinasi $\left(\mathrm{R}^{\wedge} 2\right)$ Cross-section fixed (dummy variables)

\begin{tabular}{lllr}
\hline R-squared & 0.546239 & Mean dependent var & 0.523889 \\
Adjusted R-squared & 0.612758 & S.D. dependent var & 0.305536 \\
S.E. of regression & $1.78 \mathrm{E}-14$ & Akaike info criterion & -60.20645 \\
Sum squared resid & $1.07 \mathrm{E}-26$ & Schwarz criterion & -59.46979 \\
Log likelihood & 1645.574 & Hannan-Quinn criter. & -59.92235 \\
F-statistic & 8.251226 & Durbin-Watson stat & 1.814269 \\
Prob(F-statistic) & 0.000000 & & \\
\hline Sumber: Hasil Penelitian (Diolah), 2020
\end{tabular}

86 | Jurnal Ekonomi dan Manajemen Teknologi Vol. 4 | No. 2 | 2020 
Hasil pengujian pada tabel diatas dapat diketahui nilai Adjusted $R$-Square atau nilai Koefisien Determinasi $\left(R^{2}\right)$ sebesar 0,546239. Hal ini dapat diartikan bahwa 55\% dari Income Smoothing (Perataan Laba) pada Bank Umum Syariah dan Unit Usaha Syariah di Indonesia tahun 2016-2018 dapat dijelaskan oleh variabel bebas yaitu Ukuran Perusahaan dan Financial Leverage.

Sedangkan sisanya sebesar 45\% dijelaskan oleh variabel lain yang tidak dimasukkan dalam model penelitian ini. Kemudian terdapat nilai $R$ Squared sebesar 0,612758 yang menunjukkan bahwa terdapat hubungan antar variabel sebesar $61 \%$.

\section{Penerapan Praktik Income Smoothing pada Bank Syariah}

Penerapan Income Smoothing pada Bank Syariah di Indonesia berdasarkan Fatwa Dewan Syariah Nasional No: 87/DSN-MUI/XII/2012 Tentang Metode Perataan Penghasilan Income Smoothing) Dana Pihak Ketiga yang ditetapkan pada 21 Desember 2012. Fatwa ini yang kemudian dapat dijadikan acuan bagi pihak bank syariah agar dapat melaksanakan perataan laba tanpa mengabaikan hak nasabah sebagai pemilik dana. Sehingga perbankan syariah dapat mengambil langkah yang tepat sesuai dengan peraturan-peraturan yang terdapat dalam qanun tersebut tanpa mengabaikan prinsip dasar dari perbankan syariah itu sendiri yaitu prinsip kejujuran, keadilan, tanggung jawab dan transparansi dana akuntabilitas sehingga hak nasabah juga tidak terabaikan yang akan memunculkan spekulasi yang tidak baik terhadap bank syariah itu sendiri.

\section{Kesimpulan dan Saran}

\section{Kesimpulan}

Berdasarkan hasil penelitian, hasil analisis dan pembahasan yang telah dilakukan oleh penulis mengenai pengaruh Ukuran Perusahaan dan Financial Leverage terhadap praktik Income Smoothing pada Bank Syariah di Indonesia, maka dapat ditarik kesimpulan dari keseluruhan hasil analisis sebagai berikut:

1. Ukuran Perusahaan dan Financial Leverage berpengaruh terhadap praktik Income Smoothing pada Bank Syariah di Indonesia dalam kurun waktu 3 tahun yaitu tahun 20162018 baik secara parsial maupun secara simultan.

2. Pada penelitian yang dilakukan dapat diketahui bahwa Income Smoothing yang dilakukan oleh bank syariah dapat memberikan keuntungan bagi pihak bank dan pihak nasabah. Bagi pihak bank, keuntungan yang didapatkan yaitu dapat mengelola laba dengan baik Sedangkan bagi pihak nasabah, keuntungan yang didapatkan dari praktik Income Smoothing yaitu dengan adanya pertumbuhan laba yang stabil tentu akan menjamin bahwa bagi hasil yang diperoleh juga akan lebih jelas dan meminimalisir resiko kerugian yang mungkin terjadi.

3. Praktik Income Smoothing di Indonesia juga diperbolehkan secara hukum. Hal ini dapat dibuktikan dengan dikeluarkannya Fatwa DSN No: 87/DSN-MUI/XII/2012 Tentang Metode Perataan Penghasilan Income Smoothing) Dana Pihak Ketiga.

\section{Saran}

Sehubungan dengan hasil penelitian ini, maka penulis memiliki beberapa saran sebagai berikut:

1. Diharapkan kepada perbankan syariah yang menerapkan Income Smoothing untuk tetap menjunjung nilai keadilan, kejujuran, transaparasi dana akuntabilitas dalam pelaporan keuangan kepada pihak-pihak terkait. Selain itu juga menjaga prinsip amanah dan syariah sebagai ciri khusus perbankan syariah.

2. Bagi bank syariah yang ingin menjalankan praktik Income Smoothing tersebut harus mengikuti peraturan-peraturan yang telah di tetapkan serta tidak boleh mengabaikan hak nasabah sebagai pemilik dana pihak ketiga

\section{Daftar Pustaka}

Bestivano, W. (2013). Pengaruh Ukuran Perusahaan, Umur Perusahaan, Pofitabilitas dan Financial Leverage terhadap Perataan Laba pada Perusahaan yang Terdaftar di BEI. Padang: Skripsi Universitas Negeri Padang.

Dewan Syariah Nasional-Majelis Ulama Indonesia. (2012). Fatwa DSN No. 87/DSN-MUI/XII/2012 tentang Metode 
Perataan Penghasilan (Income Smoothing) Dana Pihak Ketiga. Kemenag. Jakarta.

Dewi, Ratih Kartika dan Dra Hj. Zhulaikha, M.Si, Akt (2012). Analisis FaktorFaktor Yang Mempengaruhi Perataan laba (Income Smoothing) Pada Perusahaan manufaktur Dan Keuangan Yang Terdaftar Di BEI. Jurnal. Universitas Diponegoro Semarang.

Fahmi, I. (2013). Analisis Laporan Keuangan, Bandung: CV. ALFABETA Manufaktur yang terdaftar di Bursa Efek Indonesia), Skripsi, Bandung: Universitas Widyatama.

Djayanti, A., Fatmawati, F., (2015). Pengaruh Ukuran Perusahaan, Profitabilitas dan Financial Leverage terhadap Praktik Perataan Laba pada Perusahaan Manufaktur yang terdaftar di Bursa Efek Indonesia. Kelola, 2(3), 1-11.

Ghozali, I. (2012). Aplikasi Analisis Multivariate dengan Program IBM SPSS. ogyakarta: Universitas Diponegoro.

Ghozali, Imam. (2013). Aplikasi Analisis Multivariate dengan Program IBM SPSS 21 Update PLS Regresi. Badan Penerbit Universitas Diponegoro. Semarang.

Kusnadi. (2015). Pengaruh Profitabilitas, Debt To Equity Ratio, Struktur Kepemilikan Manajerial, Ukuran Perusahaan, Dan Risiko Perusahaan Terhadap Praktek Perataan Laba Pada Perusahaan Yang Terdaftar Di Bursa Efek Indonesia Periode Tahun 2010 - 2013. Jurnal Universitas Pandanaran: Semarang.

Masodah, M. (2007). Praktik Perataan Laba Sektor Industri Perbankan Dan Lembaga Keuangan Lainnya Dan Faktor Yang Mempengaruhinya.

Kurniawan, M. D. (2012). Faktor-Faktor Yang Berpengaruh Terhadap Perataan Laba Pada Perusahaan Manufaktur Yang Terdaftar Di Bursa Efek Indonesia (Doctoral dissertation, STIE Perbanas Surabaya).
Rahmawati, D., \& Muid, D. (2012). Analisis Faktor-faktor yang Berpengaruh Terhadap Praktik Perataan Laba (Studi pada Perusahaan Manufaktur yang Terdaftar di BEI Tahun 2007-2010) (Doctoral dissertation, Fakultas Ekonomika dan Bisnis).

Republik Indonesia. (2008). Undang-undang Nomor No.21 Tahun 2008 tentang Perbankan Syariah. Departemen Keuangan. Jakarta.

Sri Nurhayati, W. (2015). Akuntansi Syariah di Indonesia. Jakarta: Penerbit Salemba Empat.

Sudarsono, H. (2018). Bank dan Lembaga Keuangan Syariah; Deskripsi dan Ilustrasi. Ekonisia FE UII.

Sugiyono. 2014. Metode Penelitian Kuantitatif Kualitatif dan kombinasi Cetakan ke-5. Alfabeta. Bandung.

Sulistyanto, H. S. (2014). Manajemen Laba Teori dan Metode Empiris. Jakarta: Grasindo.

Tiara, H. (2012). Pengaruh Ukuran Perusahaan dan Profitabilitas Terhadap Struktur Modal Pada Perusahaan Wholesale and Retail Trade yang Terdaftar di Bursa Efek Indonesia Periode 2008-2010. Jurnal Akuntansi Kontemporer, 1(2), 1-15.

Umar, H. (2011). Metode Penelitian untuk Skripsi dan Tesis Bisnis Edisi 2. Jakarta: PT. RajaGrafindo Persada.

Utomo dan Baldric Siregar. (2008). Pengaruh Ukuran Perusahaan, Profitabilitas, dan Kontrol Kepemilikan Terhadap Perataan Laba Pada Perusahaan Manufaktur Yang Terdaftar Di Bursa Efek Indonesia (BEI). Jurnal Akuntansi dan Manajemen, 19(2).

https://www.ojk.go.id/id/kanal/syariah/datadan-statistik/statistik-perbankansyariah/default.aspx 